\title{
Comprehensive Economic Analysis of Low-rise Steel Residence in the South of Jiangsu Province
}

\author{
Yimiao $\mathrm{Li}^{1, \mathrm{a}}$, Dengfeng Wang ${ }^{2, \mathrm{~b}}$ \\ ${ }^{1}$ School of Environment and Civil Engineering Jiangnan University, WuXi, China 214122 \\ ${ }^{2}$ School of Environment and Civil Engineering Jiangnan University, WuXi, China 214122 \\ a1609501549@qq.com, 'happywdf@126.com
}

Keywords: Low-rise residence; Steel structure; Concrete structure; Comprehensive economic benefit; Comparison and analysis

\begin{abstract}
The feasibility and advantage of steel structure applied to low-rise residences in the south of Jiangsu were analyzed firstly. In order to compare the comprehensive economic benefits between the steel structure residence and the traditional reinforced concrete residence, two-story houses with steel structure and reinforced concrete structure system were designed respectively on the basis of the certain foundation and load conditions in southern area of Jiangsu. The calculation and comparison of specific economic indicators show that the labor cost of low-rise steel structure residence is significantly lower than that of concrete residence while the material costs of low-rise steel residence are more. Generally, the total cost of steel structure is slightly more expensive than that of concrete structure. However, for the long-term comprehensive economic benefits, the application of steel structure in low-rise residences is not more disadvantageous compared with concrete structure. The research work has some reference value for popularization low-rise steel structural residences in the south of Jiangsu.
\end{abstract}

\section{1 introduction}

Construction of small town in China has developed rapidly in recent years, then a large number of the residential building of the goods have been built. In long-span structure and high-rise structure, steel structure's basic theory and applications have had a more perfect result. In the field of multi-storey and high-rise residential areas, some successful experience in engineering have been accumulated. But in terms of the application and promotion, the study of steel structure mostly focuses on the city multi-storey and high-rise housing. Applied in the research and application of low-rise town residences are very little. The feasibility and comprehensive economic benefits of the application of steel structure in small residences in the south of Jiangsu are mainly discussed.

In southern regions of Jiangsu, the economy is developed and the urbanization level is high, so it has the advantage of promoting small steel structure residential industrialization.

2 the feasibility of promoting low-rise steel structure residential industrialization in the town of south Jiangsu

2.1 the support of national policy

In southern regions of Jiangsu, residence mostly uses brick structure and reinforced concrete structure now. There are many disadvantages. The dead weight is big, the space utilization is low. Cement production destroys vegetation and causes grievous atmosphere pollution. In addition, construction of energy consumption is high.Massive labor resource is occupied. Currently China vigorously promotes energy conservation and environmental protection, reduces the labor burden, so that building industrial production is gradually achieved. [2]

\section{2 saving energy and protecting environment}

Steel structure is component in the factory. Thus the construction site is neat and clean. In addition, it can reduce water consumption. Steel structure residence has the characteristics of saving energy, water, land and materials.

2.3 superior structure performances

2.3.1 light weight and simple construction foundation

Steel dwelling walls generally use light composite thermal insulation wallboard. The quality of per square metre of floor area is much less than the dead weight of reinforced concrete structure. Because that building self-weight is light and the building has lower demand for carrying 
capacity of foundation on foundation, so the treatment of basement and foundation can be simple.

2.3.2 high bearing strength,superior seismic behavior

The weight of the steel structure is lighter. The weight of the six layers of lightweight steel residence is equivalent to the weight of the four layers of brick concrete structure building. Therefore, seismic action of itself is small. And steel materials have good extensibility and long-period. Under the large deformation, steel materials can absorb deformation energy. Its integral bearing capacity and seismic behavior is far above generally steel-concrete structure, thus it can reduce many detailing requirements about anti-seismic and reduce project cost.

\section{4 superior economic performance}

Steel structure residence is build up building, its structural components are all transported to construction site after manufacturing in factories. Assembled on site has advantages of fast construction speed and short construction term. In the course of construction, the requirement of professional construction person is less. Thus comprehensive construction cost can be reduced.

\section{5 enough material}

At present, most steel structure residence often adopts ordinary iron in China. Only a little use high strength and low alloy steel. The quantity, variety, quality of steels, member and panel of buildings are already able to meet the needs of the steel frame residential building. Specifications for materials are various. And they can be directly bought in building materials market.

\section{6 technical standard perfection}

Steel structure applies to residential industry.In the aspect of material, design, manufacture, operation and acceptance, it has guidance of mature technical standard as well as matched policy and regulations.In addition, Special Components of light weight steel structure also are already put into used for quite a time and it can guarantee that can apply to residential industry.

\section{7 functional advantages}

With the rapid development of our economy and urbanization, housing demands from urban and rural citizens are turning from the quantity of the pursuit of living space to the quality of living. Especially in the south of Jiangsu, resident living standard is high, inhabitant's requirement of residential project is constantly improving. They hope residence could have the space of big-span. Steel structure residence can utilize the characteristics of high strength steel. By using the arrangement of column of large bay, it provides the possibility of changing the structure for users. In addition, because the size of steel member section is small, it can increase usable area and improve the rate of room occupancy.

In conclusion, steel structure in urban residential buildings has dominant advantages. The main reason of limiting its wide application is that conventional wisdom holds that the cost of steel structure is significantly higher than traditional structure. Economic analysis of low-rise steel structural residence is specifically analyzed below.

\section{3 economic analysis of low-rise steel structural residence}

In order to intuitively compare the difference where steel structure and reinforced concrete structure apply to economic analysis of low-rise steel structural residence in the south of Jiangsu province, now a two-story house is designed and its architectural layout shows in Figures 1 and 2.

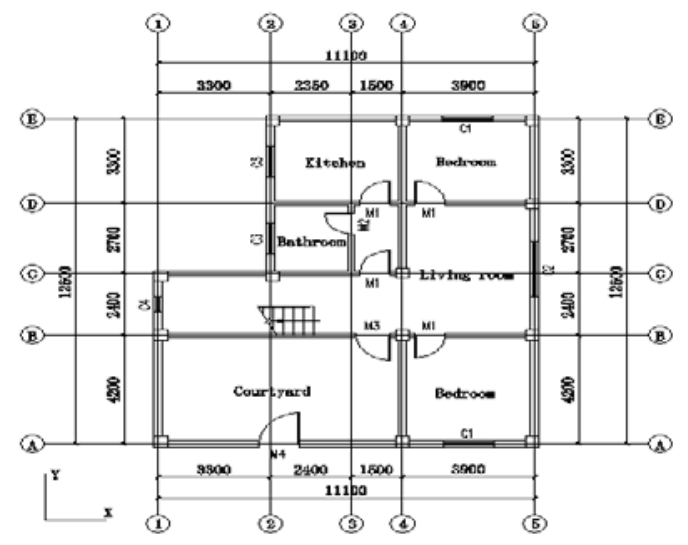

Fig. 1 First floor plan

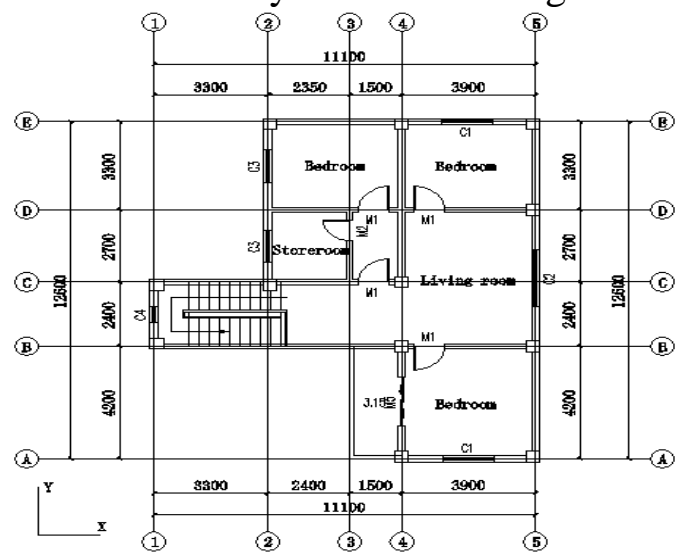

Fig. 2 Second floor plan 


\section{1 project profile}

In order to be comparable, two-story home builds in the suburbs of Wuxi. Residences are conducted with steel structure system and reinforced concrete structural system. Their floor height is 3.0 meters. Building area is 220.83 square meters. Layout and foundation conditions etc are same. Construction cycle of steel structure system is two or three months while the reinforced concrete structural system is eight or nine mouths.

\section{2 evaluation of design parameters}

Structure importance coefficient is 1.0 . Characteristic value of live load on roof is $0.3 \mathrm{kN} / \mathrm{m}^{2}$. Characteristic value of dead load is $3.0 \mathrm{kN} / \mathrm{m}^{2}$. Load simulation in the course of construction is considered. Wind loads of $x$ and $y$ direction are considered. Wind reference pressure is $0.4 \mathrm{kN} / \mathrm{m}^{2}$. Reference snow pressure is $0.4 \mathrm{kN} / \mathrm{m}^{2}$. Earthquake loading of $\mathrm{x}$ and y direction is considered. Earthquake fortification intensity is 6 degrees.

3.3 engineering metrics

Table 1 engineering metrics

\begin{tabular}{|c|c|c|}
\hline & Steel structure & Reinforced concrete structure \\
\hline Base form & strip foundation & strip foundation \\
\hline Structure system & $\begin{array}{l}\text { lightgage steel joist } \\
\text { (cold-formed steel)system }\end{array}$ & $\begin{array}{l}\text { steel-concrete structure, the main } \\
\text { supporting system is column and } \\
\text { beam }\end{array}$ \\
\hline Metope system & $\begin{array}{l}\text { The thickness of ALC plate } \\
\text { of external walls is } 150 \mathrm{~mm} \text {, } \\
\text { which amounts to } 160 \mathrm{~mm} \text { in total } \\
\text { including plaster on both sides. }\end{array}$ & $\begin{array}{l}\text { The thickness of hollow brick } \\
\text { is } 240 \mathrm{~mm} \text {, which amounts to } \\
\text { 280mm in total including plaster } \\
\text { on both sides. }\end{array}$ \\
\hline Roofing system & $\begin{array}{l}\text { Steel deck-concrete } \\
\text { composite slab(overlying ground } \\
\text { pearl block and coal cinder) }\end{array}$ & $\begin{array}{lrr}\text { Cast-in-place } & \text { concrete } & \text { roof } \\
\text { board(overlying } & \text { ground } & \text { pearl } \\
\text { block and coal cinder) } & \end{array}$ \\
\hline Floor system & $\begin{array}{l}\text { Profiled sheeting-concrete } \\
\text { composite slabs }\end{array}$ & Cast-in-place concrete slab \\
\hline $\begin{array}{l}\text { The form of doors } \\
\text { and windows }\end{array}$ & $\begin{array}{c}\text { Plastic steel window, } \\
\text { decorative wooden door }\end{array}$ & $\begin{array}{cc}\text { Plastic steel } & \text { window, } \\
\text { decorative wooden door } & \end{array}$ \\
\hline
\end{tabular}

\section{$3.4 \quad$ project cost analysis}

According to the actual situation of this project and current market prices as well as the practical experience of steel structure residence that have been built, cost analysis of main division component project was listed.

Table 2 Cost comparison of main division component project

\begin{tabular}{|c|c|c|c|c|c|}
\hline \multirow{2}{*}{\multicolumn{2}{|c|}{ The name of disciplines }} & \multicolumn{2}{|c|}{ Steel structure } & \multicolumn{2}{|c|}{$\begin{array}{c}\text { Reinforced concrete } \\
\text { structure }\end{array}$} \\
\hline & & Dosage & Cost & Dosage & Cost \\
\hline \multirow{10}{*}{$\begin{array}{l}\text { Mat } \\
\text { e-ri } \\
\text { als } \\
\text { exp } \\
\text { e-n } \\
\text { ses }\end{array}$} & Shape steel & $35.9 \mathrm{~kg} / \mathrm{m}^{2}$ & 300yuan $/ \mathrm{m}^{2}$ & 0 & 0 \\
\hline & Steel & $13.2 \mathrm{~kg} / \mathrm{m}^{2}$ & 54yuan $/ \mathrm{m}^{2}$ & $32.3 \mathrm{~kg} / \mathrm{m}^{2}$ & $198 y u a n / \mathrm{m}^{2}$ \\
\hline & Concrete & $0.172 \mathrm{~m}^{3} / \mathrm{m}^{2}$ & 60.2 yuan $/ \mathrm{m}^{2}$ & $0.38 \mathrm{~m}^{3} / \mathrm{m}^{2}$ & 133yuan $/ \mathrm{m}^{2}$ \\
\hline & The air concrete block & $0.25 \mathrm{~m}^{2} / \mathrm{m}^{2}$ & 220yuan $/ \mathrm{m}^{2}$ & 0 & 0 \\
\hline & Forms & $0.96 \mathrm{~m}^{2} / \mathrm{m}^{2}$ & 18.9yuan $/ \mathrm{m}^{2}$ & $2.15 \mathrm{~m}^{2} / \mathrm{m}^{2}$ & 64.5yuan $/ \mathrm{m}^{2}$ \\
\hline & $\begin{array}{l}\text { Fireproof-anti-corrosion } \\
\text { coatings }\end{array}$ & $0.21 \mathrm{~m}^{3} / \mathrm{m}^{2}$ & 0.21 yuan $/ \mathrm{m}^{2}$ & 0 & 0 \\
\hline & Cement & $50 \mathrm{~kg} / \mathrm{m}^{2}$ & 0.41yuan $/ \mathrm{kg}$ & $220 \mathrm{~kg} / \mathrm{m}^{2}$ & 0.41 yuan $/ \mathrm{kg}$ \\
\hline & Wood & $0.0002 \mathrm{~m}^{3} / \mathrm{m}^{2}$ & $0.09 y u a n / \mathrm{m}^{3}$ & $0.1 \mathrm{~m}^{3} / \mathrm{m}^{2}$ & 0.09 yuan $/ \mathrm{m}^{3}$ \\
\hline & Gravel & $200 \mathrm{~kg} / \mathrm{m}^{2}$ & 0.02yuan $/ \mathrm{kg}$ & $1000 \mathrm{~kg} / \mathrm{m}^{2}$ & 0.02 yuan $/ \mathrm{kg}$ \\
\hline & Foundation & - & 36.8yuan $/ \mathrm{m}^{2}$ & - & 50.2 yuan $/ \mathrm{m}^{2}$ \\
\hline
\end{tabular}




\begin{tabular}{c|c|c|c|c}
\hline Cost of labor & - & $98.24 \mathrm{yuan} / \mathrm{m}^{2}$ & - & $224.00 \mathrm{yuan} / \mathrm{m}^{2}$ \\
\hline Mechanical cost & - & $76.53 \mathrm{yuan} / \mathrm{m}^{2}$ & - & $37.31 \mathrm{yuan} / \mathrm{m}^{2}$ \\
\hline Management fee and profit & - & $102.79 \mathrm{yuan} / \mathrm{m}^{2}$ & - & $72.98 \mathrm{yuan} / \mathrm{m}^{2}$ \\
\hline
\end{tabular}

We can draw the following conclusions from the above analysis and comparison:

(1)The wall of low-rise steel structure housing uses ALC plate. Compared with the block, it can make superstructure lighter. So dosage of supporting steel structure can be saved and usable area can be enlarged.

(2)The total steel usage of low-rise steel structure housing is apparently more than reinforced concrete frame structure housing. It is 1.52 times as high as reinforced concrete frame structure. It is the main reason that leads to high cost of steel structure residence.

(3)Self-weight of low-rise steel structure housing is lighter than reinforced concrete frame structure. The foundation load is also lower, so that the cost of foundation engineering is reduced.

(4)The cost of fireproofing and corrosion protection of steel structure residence is high, so the total cost of steel structure residence is influenced.

Project cost analysis of steel structure and reinforced concrete structure is showed in table 3. Table 3 Project cost analysis[/yuan]

\begin{tabular}{c|c|c|c}
\hline \multicolumn{2}{c|}{} & Steel structure & Reinforced concrete structure \\
\hline \multirow{2}{*}{$\begin{array}{l}\text { Sub-e } \\
\text { ngine } \\
\text { ering } \\
\text { fee }\end{array}$} & Cost of labor & 21694 & 49465 \\
\cline { 2 - 4 } & Materials expense & 182399 & 144971 \\
\cline { 2 - 4 } & $\begin{array}{l}\text { Mechanical cost } \\
\text { and profit }\end{array}$ & 16900 & 8240 \\
\hline \multicolumn{2}{c}{ Step item cost } & 22699 & 16117 \\
\hline \multicolumn{2}{c}{ Other fee } & 160673 & 159066 \\
\hline Regulate fee & 20000 & 20000 \\
\hline \multicolumn{2}{c}{ Tax } & 18191 & 15445 \\
\hline \multicolumn{2}{c}{ Total price of work } & 15224 & 14218 \\
\hline
\end{tabular}

From table 3, we can come to the conclusions:

(1)The cost of labor of steel structure residence is much lower than reinforced concrete structure residence. In recent years, human unit price has higher-than-desirable growth rate. The advantage of low cost of labor during the construction of steel structure is becoming more and more apparent.

(2)Materials expense of steel structure residence is outclass steel concrete structure's. It is main reason that leads to high cost of steel structure residence. Along with the optimization of structural design and the application of new materials, materials expense still has the room for further lowering.

(3)The total cost of steel structure residence are $7 \%$ higher than steel concrete structure residence's. In general, the difference of two structural forms is not very.

To approach a fuller analyzing of the comprehensive economical performance of steel structure and reinforced concrete structure, other indicators ${ }^{[5]}$ are listed below.

Table 4 Analyzed in other indicators

\begin{tabular}{c|c|c|c}
\hline Project name & Steel structure & $\begin{array}{c}\text { Reinforced } \\
\text { concrete structure }\end{array}$ & \multicolumn{1}{|c}{ Remark } \\
\hline Area utilization rate & $93 \%-95 \%$ & $88 \%-92 \%$ & Dismantle nonbearing wall \\
\hline $\begin{array}{c}\text { Planar } \\
\text { transformation rate }\end{array}$ & $>85 \%$ & $>80 \%$ & $\begin{array}{c}\text { By energy-saving usual } \\
\text { practice, regard the reinforce } \\
\text { concrete structure as basic(1.0) }\end{array}$ \\
\hline Energy applied & $0.75-0.83$ & 1.0 & \\
\hline $\begin{array}{c}\text { Product volume of } \\
\text { construction }\end{array}$ & $0.3-0.4$ & $1.0-1.3$ & \\
\hline
\end{tabular}




\begin{tabular}{c|c|c|c}
\hline wastes( $\left(\mathrm{T} / \mathrm{m}^{2}\right)$ & $20 \%-30 \%$ & $\leq 10 \%$ & \\
\hline $\begin{array}{c}\text { Recycling rate of } \\
\text { materials }\end{array}$ & $0.29-0.38$ & 1.0 & $\begin{array}{c}\text { Regard the reinforce concrete } \\
\text { structure as basic(1.0) }\end{array}$ \\
\hline $\begin{array}{c}\text { On-the-spot water } \\
\text { and electricity } \\
\text { consumption }\end{array}$ & 0.33 & 1.0 & $\begin{array}{c}\text { Regard the reinforce concrete } \\
\text { structure as basic(1.0) }\end{array}$ \\
\hline Construction noise
\end{tabular}

From table 4, we can come to the conclusions:

(1)Steel structure system has non-beam and non-column. Area utilization rate is $93 \%-95 \%$. The room span of steel structure residence is big. Its plane reconstruction is better.

(2)Energy consumption of reinforced concrete building is 1.3 times as high as steel structure residence's. During use, the energy cost of steel structure residence is lower than reinforced concrete residence's. On-the-spot water and electricity consumption of steel structure are 0.3 times as high as reinforced concrete structure residence's. It can greatly reduce energy consumption. And carbon emission is low, it is in conformity with the requirements of sustainable development.

(3)Steel is a kind of green building materials. Only buildings are improved or removed, steel can recycle. Thus, steel structure architecture is honored as green building. It has the biggest advantage in terms of resource utilization.

(4)The various components of steel structure residence are processed in factories, assembled on the spot. The construction site is civilized and the wet construction is less. $90 \%$ can realize standardization and serialization. In addition, noise and dust which are produced during construction are less. It can reduce environmental pollution in cities, reduce the impact on the surrounding residents and meet the demand of protecting environment.

\section{4 conclusion}

In this paper, economical performance of low-rise steel structural residence is analyzed. Economic performance of steel structure system and reinforced concrete structural system are particular compared. The conclusion of comprehensive economical performance of small steel structural residence in the south of Jiangsu province is reached:

(1)Project cost of steel structure residence is slightly higher than reinforced concrete residence's. The main factor is that materials expenses of steel structure are high but the characteristic of low cost of labor of steel structure residence is outstanding.

(2)Now, materials expenses of steel structure residence are also much higher than reinforced concrete structure's. It is the main reason that the cost of steel structure residence is high.

(3)In addition, because steel structure residences have the advantages of attractive appearance, high space utilization, high structural strength and low energy consumption. So they have much more value than reinforced concrete structure residences.

In the grand scheme, economic analysis of steel structural residences has no disadvantages than steel concrete residences. It has some reference value for generalizing low-rise steel structure residence in the south of Jiangsu. And it has theoretical and practical significance for guiding commercial process of small town residence.

\section{References:}

[1] Qi Chen. Study on Steel Structure Housing Industrialization Promotion in Jiangsu Province:[Master's thesis].NanJing:Nanjing University of Technology.(2006)

[2] Xiaowei Zhu. Study on Contrastive Evaluation of Steel Structure House and Traditional House: [Master's thesis].ZheJiang:Zhejiang University.(2011)

[3] Pingzhou Cao,Shaoquan Zhu. Steel Structure.3.BeiJing:China Electric Power Press.(2008)

[4] Building Structural Load Code(GB 5009-2012)

[5] Chang Shu. The Teehno-economic Analysis Of Steel-structured Residential Housing and the Research On The Modernization Of The Housing Industry:[Master's thesis].WuHan:WuHan University Of Technology.(2005) 